\title{
THE ROLE OF NON-STATE PENSION FUNDS IN THE FORMATION OF PENSION SAVINGS OF CITIZENS OF UKRAINE
}

Удк 369.542 (477)

https://doi.org/10.32843/bses.55-31

\author{
Приймак I.I. \\ к.е.н., доцент, \\ доцент кафедри \\ фрінансів, грошового обігу і кредиту \\ Львівський національний університет \\ імені Івана Франка \\ Мацькова В.В. \\ магістрант \\ Львівський національний університет \\ імені Івана Франка \\ Pryimak Iryna \\ Ivan Franko National University of Lviv \\ Matskova Vladyslava \\ Ivan Franko National University of Lviv
}

\begin{abstract}
У статті обгрунтовано необхідність розвитку недержавного пенсійного забезпечення задля підвищення добробуту громадян після виходу на пенсію, а також розкрито роль недержавних пенсійних фондів (НПФ) у фрормуванні пенсійних заощаджень. Встановлено, що у 2014-2019 рр. скоротилась кількість фоондів, практично не зростали кількість учасників НПФ та сума пенсійних внесків, а основними напрямами інвестування пенсійних активів НПФ були державні цінні папери та банківські депозити. За допомогою кореляційного та регресійного аналізу досліджено вплив окремих чинників на вартість активів НПФ, зокрема встановлено, що інфрляція та зростання обсягу банківських депозитів призводять до ї̈ зниження, а збільшення доходів населення та видатків державного бюджету на соціальний захист, навпаки, сприяє їі зростанню. До основних проблем, що перешкоджають збільшенню популярності послуг НПФ для формування пенсійних заощаджень громадян, відносимо політичну та макроекономічну нестабільність у країні; відсутність державної роз'яснювальної кампанії про необхідність та переваги формування додаткових пенсійних заощаджень; низький рівень інвестиційного доходу НПФ; високу вартість послуг НПФ; відсутність механізму державного гарантування збереження пенсійних заощаджень громадян.

Ключові слова: пенсійні заощадження, недержавне пенсійне забезпечення, недержавний пенсійний фоно, пенсійні внески, пенсійні активи, пенсійні виплати.
\end{abstract}

В статье обоснована необходимость развития негосударственного пенсионного обеспечения с целью повышения благосостояния граждан после выхода на пенсию, а также раскрыта роль негосударственных пенсионных фондов (НПФ) в формировании пенсионных сбережений. Установлено, что в 2014-2019 г2. сократилось количество фондов, практически не росли количество участников НПФ и сумма пенсионных взноСов, а основными направлениями инвестирования пенсионных активов НПФ были государственные ценные бумаги и банковские депозиты. С помощью корреляционного и регрессионного анализа исследовано влияние отдельных фракторов на стоимость активов НПФ, в частности установлено, что инсрляция и рост объема банковских депозитов приводят к ее сокращению, а увеличение доходов населения и расходов государственного бюджета на социальную защиту, наоборот, способствует ее повышению. $K$ основным проблемам, которые препятствуют увеличению популярности услуг НПФ для формирования пенсионных сбережений граждан, относим политическую и макроэкономическую нестабильность в стране; отсутствие государственной разъяснительной кампании о необходимости и преимуществах формирования дополнительных пенсионных сбережений; низкий уровень инвестиционного дохода НПФ; высокую стоимость услуг НПФ; отсутствие механизма государственного гарантирования сохранности пенсионных сбережений граждан.

Ключевые слова: пенсионные сбережения, негосударственное пенсионное обеспечение, негосударственный пенсионный фонд, пенсионные взносы, пенсионные активы, пенсионные выплаты.

According to world experience, one of the most effective ways of social protection of the population after retirement is the construction of multi-level pension systems, which combine a joint pension, a mandatory funded pension and a private supplementary pension. However, for more than 15 years, Ukraine has been failing to carry out the planned pension reform and to achieve the development of private pension provision. The purpose of the article is to assess the activities of PPFs in the field of pension savings of citizens of Ukraine, outline the main problems of the PPF and analyze the factors that most affect their activities in modern conditions. The article substantiates the need to develop private pension provision to improve the welfare of citizens after retirement, as well as reveals the role of private pension funds (PPF) in the formation of pension savings. It was found that Ukrainians are unlikely to use the services of PPFs due to low incomes and lack of information about their benefits. The paper analyzes the activities of PPF in Ukraine in 2014-2019, and as a result of this analysis it was established: there was a reduction in the number of funds; there is practically no tendency to increase the number of PPF participants; low increase in pension contributions, the main payers of which are legal entities; the main areas of investment in pension assets of NPFs are government securities (46\%) and bank deposits (39\%). Correlation and regression analysis examined the impact of individual factors on the value of PPF assets, in particular, it was found that inflation and growth of bank deposits lead to its reduction, and increasing household incomes and state budget expenditures on social protection on the contrary contribute to its increase. The main problems hindering the growing popularity of PPF services for the formation of pension savings of citizens include: political and macroeconomic instability in the country; the low popularity of pension reform and the lack of a state awareness campaign on the need and benefits of additional pension savings; low level of investment income received by PPFs; high cost of PPF services; irregular payment of pension contributions, as well as the lack of a mechanism for state guarantee of preservation of pension savings of citizens. Key words: pension savings, private pension provision; private pension fund; pension contributions, pension assets, pension benefits.

Постановка проблеми. Завдання кожної пенсійної системи полягає у забезпеченні громадянам, які досягли пенсійного віку, такого рівня доходів, який дасть змогу запобігти бідності та зберегти гідний рівень життя. Світова практика свідчить про те, що найефеективнішими $є$ багаторівневі пенсійні системи, які поєднують солідарну та обов'язкову або добровільну додаткову пенсію. Сьогодні в Україні понад 11,3 млн. пенсіонерів отримують тільки солідарну пенсію, середній розмір якої станом на 1 січня 2020 р. складає 3 082,98 грн., або 130 дол. Цієї суми зовсім недостатньо для того, щоб гідно жити після виходу на пенсію. Водночас на рівень солідарних пенсійних виплат суттєво 
впливають демографрічна ситуація (зростання кількості пенсіонерів та скорочення економічно активного населення), економічна ситуація в країні та значний дефріцит бюджету Пенсійного фронду.

Ситуацію мала змінити пенсійна реформа, що стартувала ще у 2004 р., яка передбачала запровадження обов'язкового накопичувального пенсійного страхування. Вона ж мала дати поштовх до розвитку недержавного пенсійного забезпечення як основного механізму фрормування пенсійних заощаджень громадянами нашої країни, однак суттєвих зрушень у цій сфері так і не відбулося. Українці зазвичай або не знають про недержавне пенсійне забезпечення, або не мають достатнього рівня доходів, щоб фрормувати додаткові пенсійні заощадження. Попри всі недоліки та за умов зваженої соціальної політики держави недержавне пенсійне забезпечення у багатьох країнах світу $€$ есрективним інструментом для одержання додаткової пенсії. Для пошуку шляхів виходу з цієї ситуації необхідно з'ясувати причини низької ефективності діяльності недержавних пенсійних фрондів (НПФ) у системі недержавного пенсійного забезпечення та провести аналіз чинників, які впливають на їхній розвиток в умовах сьогодення.

Аналіз останніх досліджень і публікацій. Проблеми фрункціонування недержавних пенсійних фрондів, результативність та ефрективність їхньої роботи, особливості інвестиційної діяльності фондів широко досліджували вітчизняні науковці та практики. Зокрема, серед останніх досліджень у цій сорері варто виділити аналіз теоретичних підходів до визначення сутності поняття «недержавний пенсійний фонд» та його функцій, проведений М. Ріппою та Я. Шимком [1]; оцінювання особливостей функціонування системи НПФ у сучасних умовах, здійснене М. Дзямуличем та Н. Чиж [2]; окреслення Н. Ткаченко основних векторів і ризиків інвестиційної діяльності НПФ в Україні [3]. Заслуговують на увагу також рекомендації, надані за результатами дослідження компанії "DAI Global LLC" в рамках проєкту USAID «Tрансфрормація фрінансового сектору» щодо перезавантаження недержавного пенсійного забезпечення в Україні [4]. Попри низку ґрунтовних праць у цій сорері питання підвищення есрективності НПФ як інструменту орормування пенсійних заощаджень населенням України потребує подальших наукових пошуків.

Постановка завдання. Метою статті $€$ оцінювання діяльності НПФ у сфері фрормування пенсійних заощаджень громадянами України, окреслення основних проблем функціонування НПФ та аналіз чинників, які найбільше впливають на їхню діяльність у сучасних умовах.

Виклад основного матеріалу дослідження. Суб'єктами недержавного пенсійного забезпечення, що є третім рівнем пенсійної системи України, має виключно добровільний характер та передбачає накопичення фрізичними і юридичними особами орінансових ресурсів у спеціальних установах задля одержання додаткових коштів, є:

- недержавні пенсійні фронди;

- страхові організації, які уклали договори страхування довічної пенсії з учасниками фонду, страхування ризику настання інвалідності або смерті учасника фронду;

- банківські установи, які уклали договори про відкриття пенсійних депозитних рахунків [5].

Основними фрінансовими установами, які фрормують пенсійні заощадження громадян, мали би бути недержавні пенсійні фронди. Однак українці, фрормуючи заощадження, віддають перевагу банкам, адже така фрінансова послуга, як банківський депозит, $є$ більш простою та зрозумілою. Щодо інших можливостей фрормування пенсійних заощаджень, то пересічні громадяни нашої країни або взагалі не знають про них, або не розуміють їх. Динаміку внесків громадян України до основних суб'єктів недержавного пенсійного забезпечення наведено на рис. 1.

Варто зауважити, що банки не публікують статистику щодо кількості та обсягів укладених пенсійних депозитів, тому наведена динаміка депозитів терміном понад 2 роки ілюструє лише загальну схильність та спроможність українців до фрормування довгострокових заощаджень. Попри це, можемо відзначити загальну тенденцію до скорочення довгострокових заощаджень населення після 2015 року та незначне покращення ситуації у 2018-2019 рр. Вважаємо, що саме НПФ мають стати головними фрінансовими інститутами, які акумулюватимуть додаткові пенсійні заощадження громадян України за умови успішної пенсійної рефрорми.

Недержавний пенсійний фонд (НПФ) - це неприбуткова установа, яка фрункціонує за рахунок внесків її учасників задля їхнього розподілу в майбутньому [5]. Мета діяльності такої організації полягає у захисті пенсійних заощаджень учасників фронду від іноляційного знецінення шляхом інвестування їх у різні фрінансові інструменти та проведенні виплат усім членам фонду в майбутньому. НПФ, на відміну від страхових компаній і банків, спеціалізуються виключно на збереженні фрінансових ресурсів та здійсненні пенсійних виплат громадянам [10]. Така зосередженість на збереженні коштів разом із продуманою та ефективною інвестиційною діяльністю задля зниження інфрляційного впливу може сприяти популярності НПФ на ринку заощадження коштів населення. Однак сьогодні ми не спостерігаємо великого попиту на фрінансові послуги НПФ серед населення. Про це свідчать і динаміка кількості НПФ в Україні, і основні показники їхньої діяльності (табл. 1).

Через політичну та економічну кризу в Україні, різке знецінення гривні, високий рівень інсрляції, зростання безробіття та низький рівень довіри 


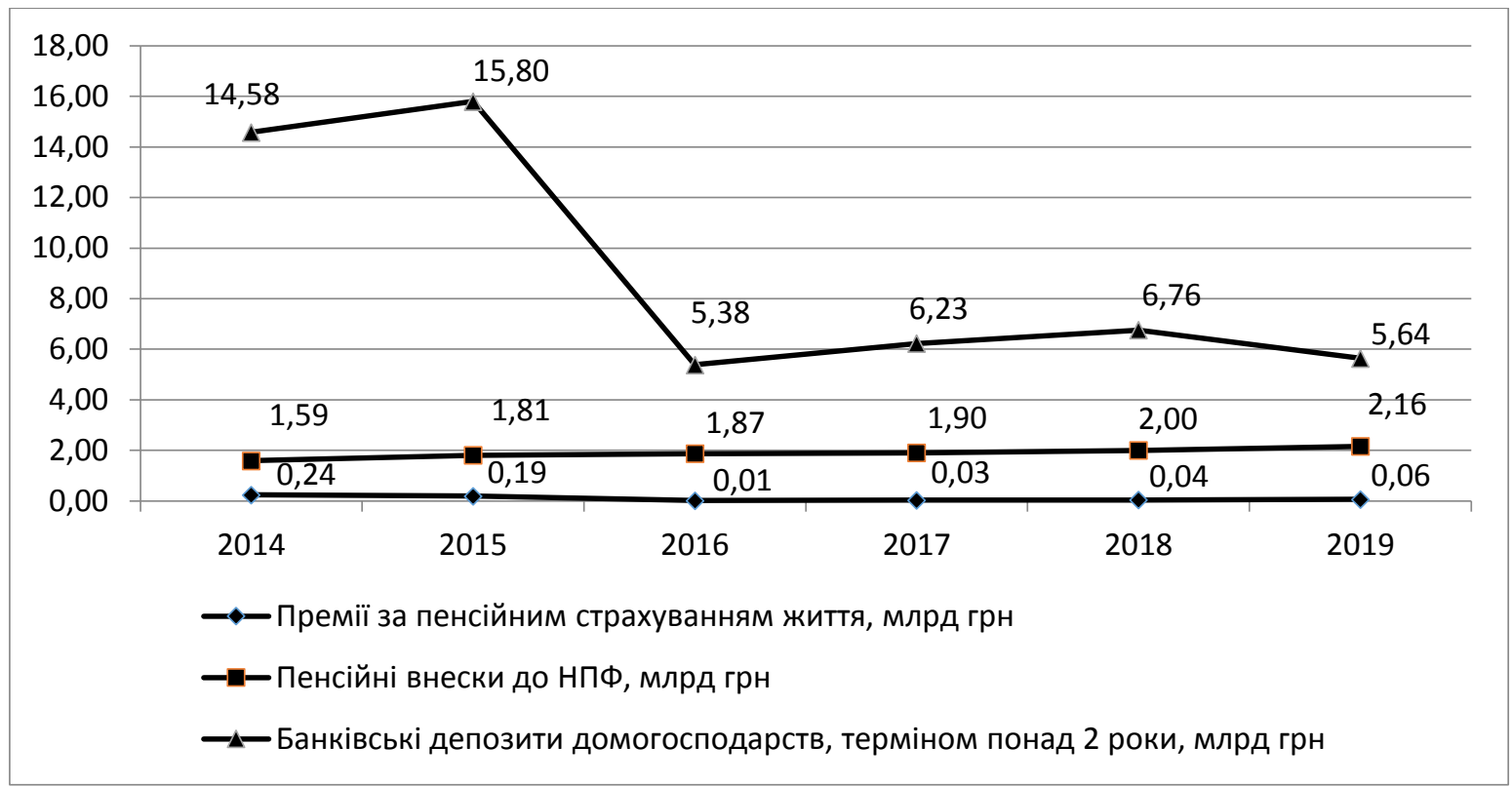

Рис. 1. Динаміка внесків громадян України для фрормування пенсійних заощаджень

Джерело: побудовано за джерелами [6; 7; 8; 9]

Таблиця 1

Основні показники діяльності НПФ в Україні у 2014-2019 рр.

\begin{tabular}{|l|c|c|c|c|c|c|}
\hline \multicolumn{1}{|c|}{ Показники } & $\mathbf{2 0 1 4}$ p. & $\mathbf{2 0 1 5}$ p. & $\mathbf{2 0 1 6}$ p. & $\mathbf{2 0 1 7}$ p. & $\mathbf{2 0 1 8}$ p. & $\mathbf{2 0 1 9}$ p. \\
\hline Кількість НПФ & 76 & 72 & 64 & 64 & 62 & 65 \\
\hline Кількість адміністраторів НПФ & 24 & 23 & 22 & 22 & 22 & 22 \\
\hline Кількість укладених пенсійних контрактів, тис. шт. & 61,4 & 55,1 & 59,7 & 58,7 & 68,8 & 77,1 \\
\hline Загальна кількість учасників НПФ, тис. осіб & 840,6 & 833,7 & 836,7 & 840,8 & 855,3 & 874,6 \\
\hline Пенсійні внески, млн. грн. & 1587,5 & 1808,2 & 1886,8 & 1897,3 & 2000,5 & 2160,8 \\
\hline - від фрізичних осіб & 66,5 & 71,4 & 80,3 & 124,3 & 172,1 & 222,7 \\
\hline - від фрізичних осіб-підприємців & 0,2 & 0,2 & 0,2 & 0,2 & 0,2 & 0,2 \\
\hline - від юридичних осіб & 1520,5 & 1736,1 & 1806,3 & 1772,3 & 1827,7 & 1937,3 \\
\hline Пенсійні виплати, млн. грн. & 300,2 & 421,4 & 557,1 & 696,3 & 809,9 & 947,4 \\
\hline $\begin{array}{l}\text { Кількість учасників, що отримують пенсійні } \\
\text { виплати, тис. осіб }\end{array}$ & 69,0 & 75,6 & 82,2 & 78,8 & 81,3 & 83,9 \\
\hline
\end{tabular}

Джерело: сорормовано за джерелами [6; 7]

населення до НПФ відбулося суттєве скорочення їхньої кількості у 2014-2016 рр. Впродовж останніх років кількість НПФ не скорочувалась, але й не відбулося зростання ринку недержавного пенсійного забезпечення.

Після 2014 р. спостерігаємо скорочення кількості пенсійних контрактів, укладених з НПФ, і тільки 32018 р. намітилась позитивна динаміка. У 2019 р. темпи приросту цього показника порівняно з 2014 р. склали 20,3\%.

Скромними залишаються також темпи приросту кількості учасників НПФ. Так, у 2019 р. цей показник становив 874,6 тис. осіб, що лише на 4\% більше, ніж у 2014 р., що свідчить про низьку популярність та відсутність довіри населення до послуг НПФ як способу фрормування пенсійних заощаджень. Це підтверджують також результати опиту- вання громадської думки, проведеного Проєктом USAID «Tрансформація фрінансового сектору» у 2017 р. щодо пенсійної реформи та ставлення до пенсій в Україні, відповідно до якого 53\% респондентів нічого не знають про недержавне пенсійне забезпечення, а 57\% не мають можливості заощаджувати на пенсію [4, с. 21].

Розмір пенсійнихвнесків доНПФ за останнішість років збільшився тільки на 573,3 млн. грн. 89,6\% пенсійних внесків становлять кошти юридичних осіб, 10,3\% - фрізичних осіб, а решта 0,1\% - фрізичних осіб-підприємців. Така структура пенсійних внесків свідчить про низьку культуру формування пенсійних заощаджень в українському суспільстві та відсутність державної політики у цій сфері.

ще меншими є суми пенсійних виплат, але така ситуація обумовлена тим, що більше половини 
учасників, а саме 57,2\%, складають особи віком від 25 до 50 років, які тільки вкладають кошти й не потребують цих виплат відповідно до свого віку, а 16,1\% вкладників складають люди старше 60 років, які, відповідно, отримують пенсійні виплати [6].

Задля убезпечення пенсійних накопичень та отримання стабільного інвестиційного доходу НПФ розміщують пенсійні активи у різні фрінансові інструменти, враховуючи встановлені законодавством обмеження, макроекономічну ситуацію, стан фондових ринків. Структуру інвестованих активів НПФ наведено на рис. 2. Левову частку пенсійних активів інвестовано у державні цінні папери (46\%) та розміщено на банківських депозитах (39\%), менш популярними для отримання інвестиційного доходу серед НПФ є облігації українських підприємств (9\%), об'єкти нерухомості (3\%) та акції українських емітентів (1\%).

Як бачимо, наявні в Україні фінансові інструменти жорстко обмежують змогу одержання інвестиційного доходу, вищого за рівень інфрляції, та можливість диверсисрікації ризиків, що ставить під сумнів здатність вітчизняних НПФ захистити пенсійні заощадження громадян від інсрляційного впливу.

Для оцінювання впливу інфрляції на фрормування пенсійних активів НПФ під час дослідження

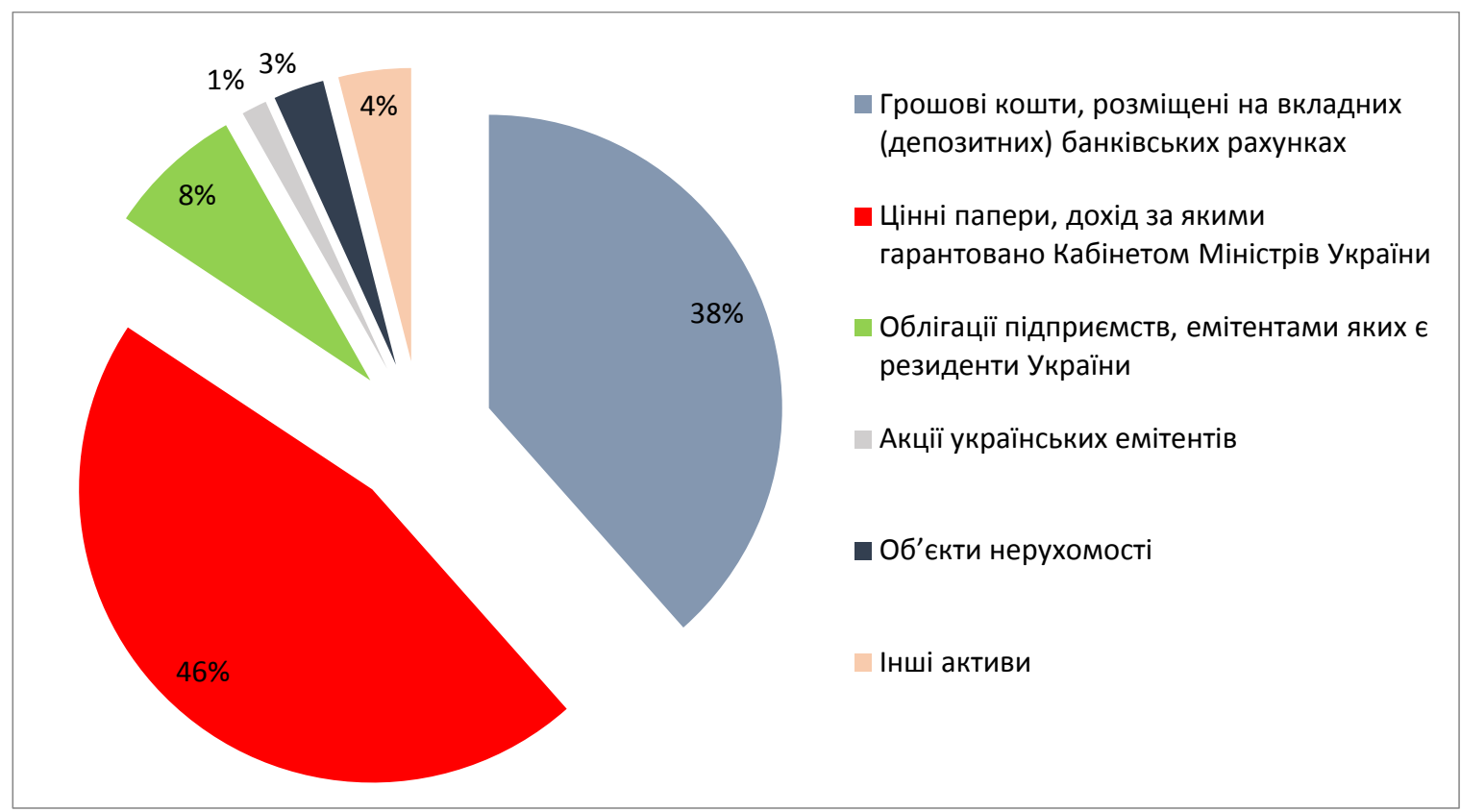

Рис. 2. Структура інвестованих пенсійних активів НПФ станом на 31 грудня 2019 р.

Джерело: побудовано за джерелом [6]

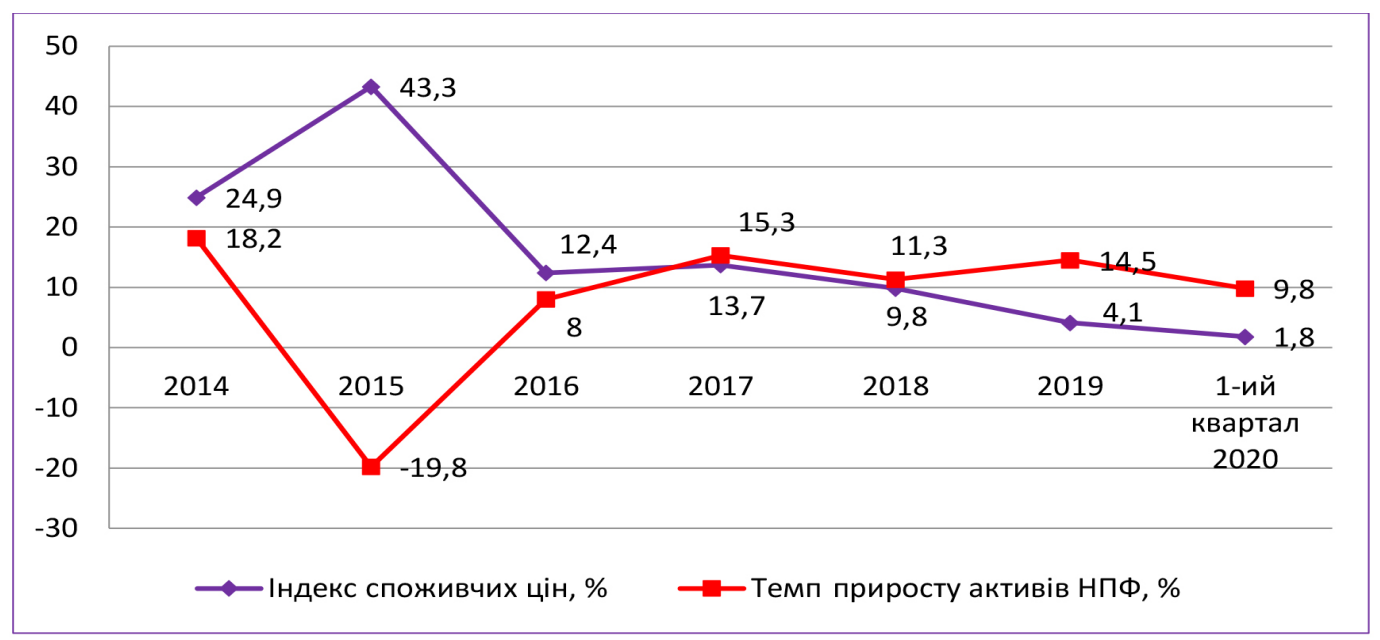

Рис. 3. Динаміка показників індексу споживчих цін та темпу приросту загальної вартості активів НПФ у 2014-2020 рр. 
розраховано коесріцієнт кореляції Пірсона між двома змінними, а саме індексом споживчих цін та темпом приросту загальної вартості активів НПФ (рис. 3). Отриманий результат $(R=-0,73538)$ свідчить про те, що між двома змінними існує значний зв'язок, а від'ємне значення вказує на протилежний вплив, тобто чим вище значення показника іноляції, тим менше темп приросту загальної вартості активів НПФ, і навпаки.

Зростання рівня інфляції приводить до збільшення вартості товарів і послуг, що суттєво знижує можливість громадян орормувати заощадження, зокрема за допомогою НПФ, а також знецінює активи НПФ. Треба зауважити, що негативно на вартість активів НПФ впливає зростання обсягу банківських депозитів фрізичних осіб. Для оцінювання інтенсивності такого впливу було використано коеоіцієнт Фехнера. Отримане значення $\left(\mathrm{K}_{\phi}=-0,33\right)$ означає, що між цими двома змінними існує достатній зворотній зв'язок, тобто, зростання суми вкладів у банківських установах приводить до зменшення активів НПФ, і навпаки. Зазвичай громадяни не думають про диверсифрікацію ризиків щодо вкладених коштів і вибирають лише одну фрінансову установу, якій довіряють та в яку інвестують свої кошти, а порівняно з банківським депозитом пенсійний контракт з НПФ для громадян $€$ незрозумілою фрінансовою послугою, тому під час конкуренції за клієнтів НПФ часто програють банкам.

Важливим чинником зростання обсягу активів НПФ є збільшення доходів населення. Кореляційний аналіз цих показників $\left(\mathrm{K}_{\mathrm{d}}=0,67\right)$ свідчить про досить сильний та прямий зв'язок. Це означає, що зростання середнього доходу на душу населення в країні сприяє збільшенню обсягу активів НПФ (рис. 4).
Позитивний вплив на вартість активів НПФ також має зростання видатків на соціальне забезпечення 3 державного бюджету України. Розрахунки показали, що для цих показників $\mathrm{K}_{\phi}=0,71$. Отже, зростання чи зменшення видатків на соціальне забезпечення прямо пропорційно впливає на суму загальної вартості активів НПФ. Зазвичай видатки на соціальне забезпечення зростають, коли економічна ситуація в країні покращується, отже, зростають добробут громадян та їхня готовність до фрормування заощаджень (рис. 5).

До основних проблем, які перешкоджають розвитку НПФ в Україні, варто віднести низький рівень доходів населення, що не дає змогу фрормувати пенсійні заощадження; слабкий розвиток фрінансових ринків; відсутність державної кампанії щодо популяризації приватних пенсійних схем; неспроможність НПФ досягнути довгострокового чистого інвестиційного доходу; великі витрати НПФ, що негативно впливають на вартість пенсійних активів у довгостроковому періоді.

Висновки з проведеного дослідження. Попри розроблену концепцію пенсійної реформи, в Україні досі працює лише солідарна пенсійна система, фрінансовий потенціал якої не дає змогу забезпечити гідний рівень життя пенсіонерам. У майбутньому з огляду на демографрічну ситуацію без невідкладних та рішучих заходів пенсійної кризи не уникнути. Натомість розвиток системи недержавного пенсійного забезпечення, яка доповнює загальнообов'язкове державне пенсійне страхування, може стати тим механізмом, що дасть змогу забезпечити гідний рівень життя після виходу на пенсію.

Нині роль НПФ у фрормуванні пенсійних заощаджень громадян $€$ мізерною, їхні послуги є надто

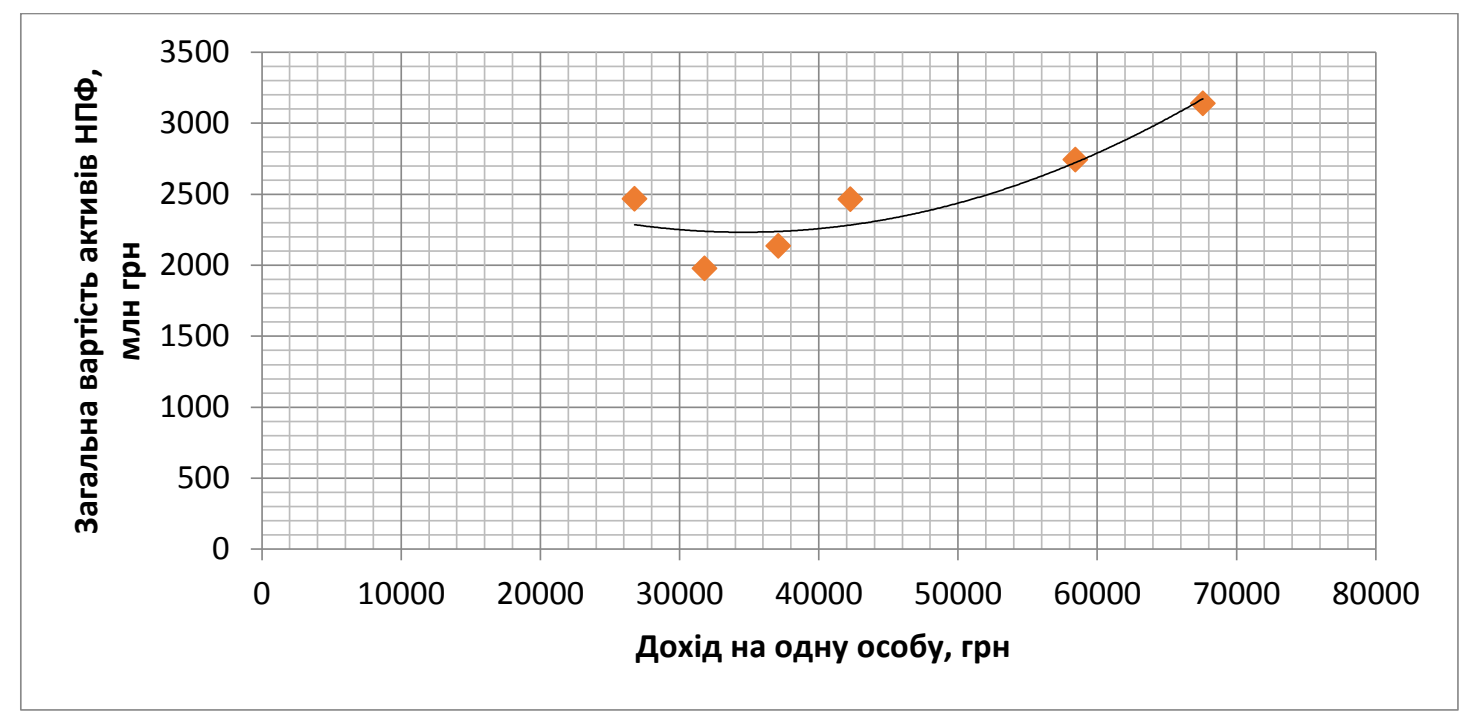

Рис. 4. Кореляційний зв'язок між вартістю активів НПФ та доходом на одну особу 


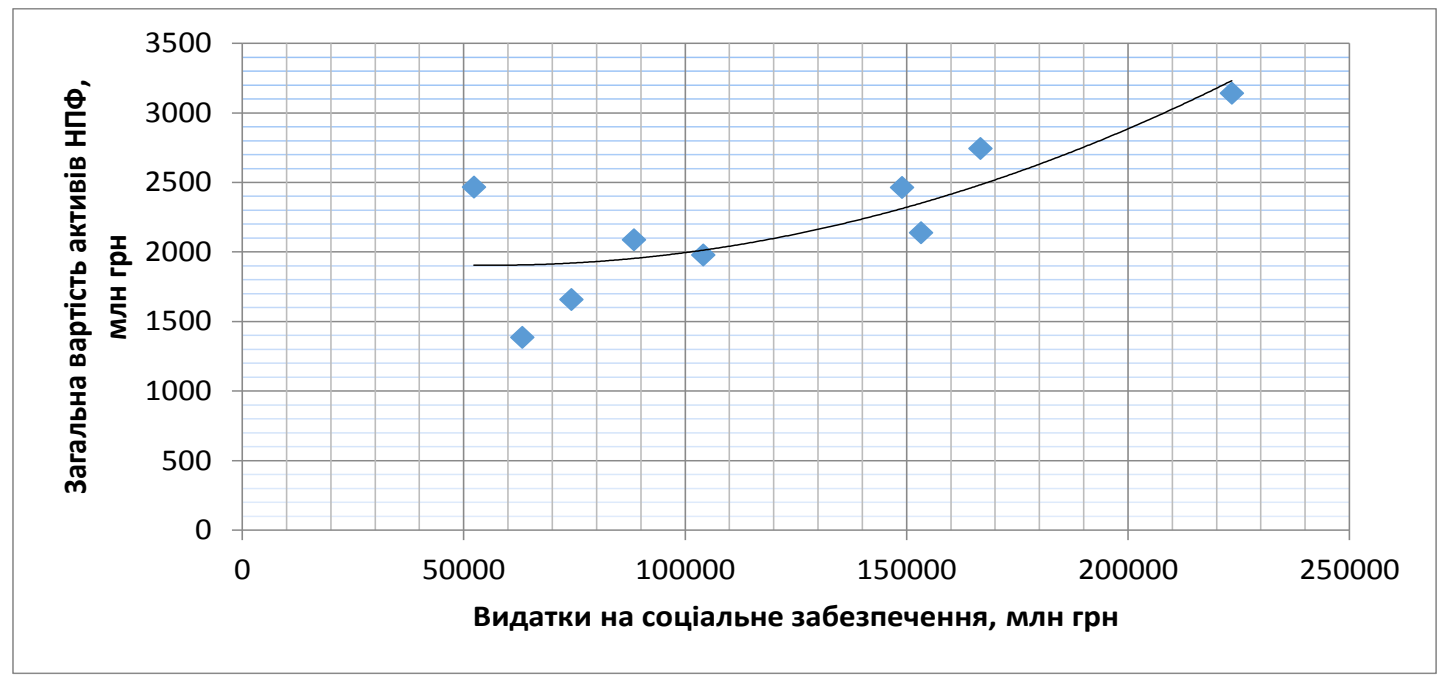

Рис. 5. Кореляційний зв'язок між загальною вартістю активів НПФ та видатками на соціальне забезпечення з державного бюджету

Джерело: побудовано за джерелами [6; 7; 14]

дорогими, а здатність забезпечити належний інвестиційний дохід - сумнівною. Отже, довіра більшості громадян до НПФ та системи недержавного пенсійного забезпечення загалом невисока.

Для стимулювання розвитку НПФ необхідно осучаснити законодавчу базу, забезпечити макроекономічну стабілізацію, сприяти розвитку фрінансових ринків, провести масштабну інсрормаційну кампанію задля підвищення обізнаності громадян у сорері фрінансового добробуту та пенсій, удосконалити систему фрінансових стимулів участі населення у приватних пенсійних схемах та вдосконалення системи контролю за витратами на оплату послуг НПФ.

\section{БІБЛІОГРАФІЧНИЙ СПИСОК:}

1. Ріппа М., Шимко Я. Економічна природа недержавних пенсійних фоондів. Економічний вісник універcumemy. 2019. № 41. C. 162-170. URL: https://doi.org/ 10.31470/2306-546X-2019-41-162-170.

2. Дзямулич М., Чиж Н. Особливості функціонування системи недержавних страхових пенсійних фондів в Україні. Економічний фрорум. 2020. № 1. С. 135-140. URL: https://doi.org/10.36910/6775-2308-8559-2020-1-19.

3. Ткаченко Н. Вектори розвитку інвестиційної діяльності недержавних пенсійних фрондів в Україні. Проблеми і перспективи економіки та управління. 2019. № 1 (17). C. 200-206 URL: https://ppeu.stu.cn.ua/ tmppdf/567.pdf.

4. Недержавне пенсійне забезпечення в Україні: оцінка та рекомендації. Звіт проєкту USAID «Трансфрормація фрінансового сектору», липень, 2019. 58 c. URL: http://www.fst-ua.info/wp-content/ uploads/2019/07/Voluntary_Private_Pensions_in_ Ukraine-Assessment jul2019 ua.pdf.

5. Про недержавне пенсійне забезпечення : Закон України від 9 липня 2003 р. № 1057-IV. URL: https:// zakon.rada.gov.ua/laws/show/1057-15.
6. Підсумки розвитку системи недержавного пенсійного забезпечення станом на 31 грудня 2019 р. / Національна комісія, що здійснює державне регулювання у сорері ринків фрінансових послуг. URL: https://www.nfp.gov.ua/files/OgliadRinkiv/NPF/NPF_ IV_kv_2019.doc.

7. Підсумки розвитку системи недержавного пенсійного забезпечення станом на 31 грудня 2016 р. / Національна комісія, що здійснює державне регулювання у сорері ринків фінансових послуг. URL: https://nfp.gov.ua/files/17_Dep_Repetska/NPF_IV_ kV\%202016.pdf.

8. Рейтинг страхових компаній України. Пенсійне страхування життя за 2014-2019 рр. URL: https://forinsurer.com/ratings/life.

9. Грошово-кредитна статистика / Національний банк України. URL: https://bank.gov.ua/ua/statistic/ sector-financial/data-sector-financial\#1ms.

10. Приймак І., Вишивана Б. Недержавне пенсійне забезпечення в системі соціального захисту населення. Світ фрінансів. 2019. Вип. 3. С. 121-138. URL:http://sf.tneu.edu.ua/index.php/sf/article/download/ 1250/1253.

11. Підсумки розвитку системи недержавного пенсійного забезпечення станом на 31 березня 2020 р. / Національна комісія, що здійснює державне регулювання у соеері ринків фрінансових послуг. URL: https://nfp.gov.ua/files/OgliadRinkiv/NPF/NPF__ kv\%202020.pdf.

12. Зведена таблиця індексів споживчих цін 3 2000 по 2020 рр. / Міністерство фрінансів України. URL: https://index.minfin.com.ua/ua/economy/index/inflation.

13. Доходи населення по регіонах України / Державна службастатистикиУкраїни.URL: http://www.ukrstat.gov.ua/ operativ/operativ2008/gdn/dvn_ric/dvn_ric_u/dn_ reg2013_u.html.

14. Річні звіти про виконання державного бюджету України за 2014-2019 роки / Державна казначейська служба України. URL: https://www.treasury.gov.ua/ua/ file-storage/vikonannya-derzhavnogo-byudzhetu. 


\section{REFERENCES:}

1. Rippa M., Shymko Ya. (2019) Ekonomichna pryroda nederzhavnyh pensiinyh fondiv [Economic nature of private pension funds]. Ekonomichnyy visnyk universytetu. Economic Bulletin of the University, 41, pp. 162-170. Available at: https://doi.org/10.31470/ 2306-546X-2019-41-162-170.

2. Dziamulych M., Chizh N. (2020) Osoblyvosti funktsionuvannya systemy nederzhavnykh strakhovykh pensiynykh fondiv $v$ Ukrayini [Peculiarities of functioning of the system of non-state insurance pension funds in Ukraine]. Ekonomichnyy forum 2020 - Economic Forum 2020, 1, pp. 135-140. Available at: https://doi.org/ 10.36910/6775-2308-8559-2020-1-19.

3. Tkachenko N. (2019) Vektory rozvytku investytsiynoyi diyal'nosti nederzhavnykh pensiynykh fondiv $v$ Ukrayini [The vectors of development of private pension funds investment actavities]. Problemy i perspektyvy ekonomiky ta upravlinnya. - Problems and prospects of economics and management, 1 (17), pp. 200-206. Available at: https://ppeu.stu.cn.ua/tmppdf/567.pdf.

4. Nederzhavne pensiyne zabezpechennya v Ukrayini: otsinka ta rekomendatsiyi. Zvit proektu USAID "Transformatsiya finansovoho sektoru" [Non-state pension provision in Ukraine: assessment and recommendations. USAID Financial Sector Transformation Project Report]. (2019, July). p. 58. Available at: http://www.fstua.info/wp-content/uploads/2019/07/Voluntary_Private_ Pensions_in_Ukraine-Assessment_jul2019_ua.pdf.

5. Pro nederzhavne pensiine zabezpechennia: Zakon Ukrainy vid 09.07.2003 roku No 1057-IV [On NonState Pension Provision: The Law of Ukraine] (2003, November, 4). Available at: https://zakon.rada.gov.ua/ laws/show/1057-15.

6. Pidsumky rozvytku systemy nederzhavnoho pensiinoho zabezpechennia stanom na 31.12.2019 [Results of the development of the system of nonstate pension provision dated December 31, 2019]. Available at: https://www.nfp.gov.ua/files/OgliadRinkiv/NPF/NPF_IV_ kv_2019.doc.

7. Pidsumky rozvytku systemy nederzhavnoho pensiinoho zabezpechennia stanom na 31.12.2016
[Results of the development of the system of nonstate pension provision dated December 31, 2016]. Available at: https://nfp.gov.ua/files/17_Dep_Repetska/NPF_IV_ kv\%202016.pdf.

8. Reytynh strakhovykh kompaniy Ukrayiny. Pensiyne strakhuvannya zhyttya za 2014-2019 rr. [Rating of insurance companies of Ukraine. Pension life insurance for 2014-2019]. Available at: https://forinsurer.com/ratings/life.

9. Hroshovo-kredytna statystyka. Natsional'nyy bank Ukrayiny [Monetary statistics. National Bank of Ukraine]. Available at: https://bank.gov.ua/ua/statistic/sectorfinancial/data-sector-financial\#1ms.

10. Pryimak I., Vyshyvana B. (2019) Nederzhavne pensiine zabezpechennia $v$ systemi sotsialnoho zakhystu naselennia Ukrainy [Non-state pension provision in the system of social protection of the Ukrainian population] Svit finansiv. World of finance, 3 (60), pp. 121-138. Available at: http://sf.tneu.edu.ua/index.php/sf/article/ download/1250/1253.

11. Pidsumky rozvytku systemy nederzhavnoho pensiinoho zabezpechennia stanom na 31.12.2020 [Results of the development of the system of nonstate pension provision dated December 31, 2020]. Available at: https:// nfp.gov.ua/files/OgliadRinkiv/NPF/NPF_ I_kv\%202020.pdf.

12. Zvedena tablytsya indeksiv spozhyvchykh tsin z 2000 po 2020 rr. [Summary table of consumer price indices from 2000 to 2020]. Ministerstvo finansiv Ukrayiny. - Ministry of Finance of Ukraine. Available at: https://index.minfin.com.ua/ua/economy/index/inflation.

13.Dokhody naselennya po rehionakh Ukrayiny [Income of the population by regions of Ukraine]. Derzhavna sluzhba statystyky Ukrayiny. - State Statistics Service of Ukraine. Available at: http://www.ukrstat.gov.ua/ operativ/operativ2008/gdn/dvn_ric/dvn_ric_u/dn_ reg2013_u.html.

14. Richni zvity pro vykonannya derzhavnoho byudzhetu Ukrayiny za 2014-2019 roky [Annual reports on the implementation of the state budget of Ukraine for 2014-2019]. Derzhavna kaznacheys'ka sluzhba Ukrayiny - State Treasury Service of Ukraine. Available at: https://www.treasury.gov.ua/ua/file-storage/vikonannyaderzhavnogo-byudzhetu. 